E.M. Demianenko, M.I. Terets, Yu.I. Sementsov, S.M. Makhno, V.S. Kuts, A.G. Grebenyuk, M.T. Kartel

\title{
THEORETICAL STUDY ON THE EFFECT OF CARBON GRAPHENOUS NANOCLUSTERS ON THE STABILITY AND CAPACITY OF POLYAMIDE IN A NANOCOMPOSITE
}

\author{
Chuiko Institute of Surface Chemistry of National Academy of Sciences of Ukraine \\ 17 General Naumov Str., Kyiv, 03164,Ukraine, E-mail: Demianenko_en@ukr.net
}

\begin{abstract}
By the density functional theory method with the exchange-correlation functional B3LYP, the basis set 6-31G(d,p) and Grimme dispersion corrections, the energy values has been calculated of intermolecular interaction between adjacent polyamide fragments, and the effect of graphene-like nanoclusters on the similar values for intermolecular complexes of polyamide fragments with graphene-like nanoclusters has been evaluated. The effect of carbon materials on the energy magnitudes of covalent bonds in the polymer matrix of polyamide has been also examined.

Comparison of the energy values of intermolecular interaction between two monomers $(-86.0 \mathrm{~kJ} / \mathrm{mol}$, two hydrogen bonds) and two dimers $(-302.0 \mathrm{~kJ} / \mathrm{mol}$, three hydrogen bonds) indicates that the energy of interaction between two components consists of that of hydrogen bonds and the energy contribution of dispersive forces.

The energy of intermolecular interaction between two dimers with the graphene matrix $\left(\mathrm{C}_{110} \mathrm{H}_{26}\right)$ is approximately $40 \mathrm{~kJ} / \mathrm{mol}$ higher $(-346.2 \mathrm{~kJ} / \mathrm{mol})$ compared to respective value for two monomers. The less value of the interaction energy $(-325.0 \mathrm{~kJ} / \mathrm{mol})$ for the nanocomposite with $\mathrm{C}_{96} \mathrm{H}_{24}$ species is due to the insufficient size of the selected model for the graphene matrix.

The analysis of the hydrogen bond lengths between the oxygen atom of carbonyl group and hydrogen one of amino group indicates that, regardless of length of linkage of the polymeric chain of polyamide (monomer and dimer) and the size of the graphene-like matrix $\left(\mathrm{C}_{96} \mathrm{H}_{24}\right.$ and $\left.\mathrm{C}_{110} \mathrm{H}_{26}\right)$ in the nanocomposite, the hydrogen bond in composites is shorter in comparison with a those values in complexes without a carbon matrix. This indicates a greater strength of the bond, that is, the presence of a carbon matrix increases the strength of the formed nanocomposite, that explains the increase in the melting point compared with that of the original polymer. In the nanocomposite formed polyamide - a carbon matrix for all the models studied, the energy of intermolecular interaction in the nanocomposite increases significantly compared to respective value between two fragments of pure polyamide, so indicating an increase in the thermal stability of this nanocomposite what is confirmed by experimental data.
\end{abstract}

Keywords: polyamide, nanocomposite, graphene-like plane, density functional theory method, cluster approximation

\section{INTRODUCTION}

Novadays one of the perspective and actual directions of development of modern applied science is obtaining polymeric nanocomposites possessing unique properties [1]. Their creation with predetermined properties is based on fundamental researches of physical and chemical processes of formation of materials and of their structure at the atomic level. In $[2,3]$ we described the efficiency of using nanosized compounds of different chemical nature, as modifiers of polymer matrices, in particular such polymers as polyethylene, polypropylene, polyamide, and so on.

As a filler, carbonaceous materials are often used, in particular thermo-exteoliated graphite [4], graphene [5] and carbon nanotubes (CNT) (C) E.M. Demianenko, M.I. Terets, Yu.I. Sementsov,
$[6,7]$. These carbon materials are considered to be the best reinforcing materials for polymers [3], which change the physical and mechanical properties of the resulting nanocomposite. In particular, it has been found that the addition of a very small amount (up to $5 \%$ by weight) of CNT to thermoplastic polymers increases the material modulus of elasticity and strength by $50 \%$ [8]. In addition, the inclusion of CNT in the polyamide matrix in small amounts (up to $5 \%$ by weight) leads to a nonmonotonic change in the degree of crystallinity of the matrix, which affects the electrophysical and thermodynamic properties of the resulting nanocomposites [9-10]. However, the effect of CNT on the properties of nanocomposites obtained on the basis of polyamide at the atomic level has not yet 
been fully elucidated. This can be done by computer simulation methods, since the interaction and properties of the composites of organic polymers with nanotubes are successfully investigated by methods of quantum chemistry [11-14]. In particular, [14] describes the interaction of graphene-like clusters as models for the external surface of nanoscale particles with polyethylene and polypropylene fragments. It is shown that the energy of the intermolecular interaction of the fragments of these polymers with graphene-like clusters is greater than that in the case of mutual interaction of polymer fragments, what is explained by an increase in the tensile strength and thermal stability of the formed nanocomposites compared with the initial polymers $[15,16]$.

It is known [17] that for thermoplastic polymers (including polyamide), the intermolecular binding energy between their structural units correlates with the melting temperature of the corresponding polymer. Therefore, in order to determine the influence of the addition of carbon materials on the stability and strength of the resulting polyamidecontaining nanocomposites, the interaction energy $(\Delta E)$ of neighboring polyamide fragments was calculated in this work and in as well as respective $\Delta E$ values for the intermolecular complexes of polyamide fragments with graphene nanoclusters. The effect of carbon materials on the energy values of covalent bonds in the polymer matrix of polyamide is also examined.

\section{OBJECTS AND METHODS OF EXAMINATION}

The density functional theory (DFT) method with the functional B3LYP $[18,19]$, taking into account the dispersion correction Grimme D3 $[20,21]$. and the basis set $6-31 \mathrm{G}(\mathrm{d}, \mathrm{p})$, using the GAMESS (US) program [22], was used to calculate the energy of interaction $(\Delta E)$ between adjacent polyamide fragments (two fragments of polyamide consisting of single elementary link are used, see Fig. $1 a$ ), as well as that of the interaction between two larger fragments, each of which consists of two elementary units, see Fig. $1 b$ (hereinafter referred to as monomers and dimers).

As a fragment of carbon material, the graphene-like cluster (GC) of the gross formula of $\mathrm{C}_{96} \mathrm{H}_{24}$ was selected (Fig. $2 a$ ). In order to take into account the size effect on the investigated parameters, the graphene-like clusters of carbon polyaromatic molecules of a larger size, namely those with the $\mathrm{C}_{110} \mathrm{H}_{26}$ composition, were used (Fig. $2 b$ ).
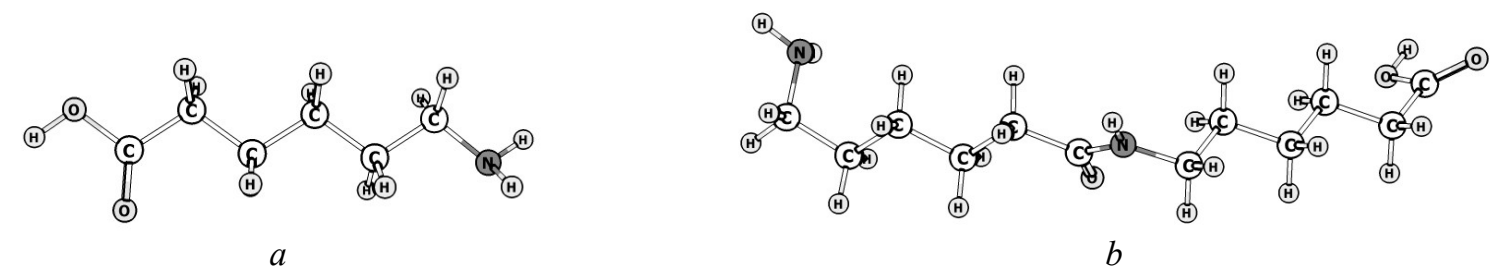

Fig. 1. Models for fragments of polyamide, consisting of: $a$ - monomer, $b$ - dimer
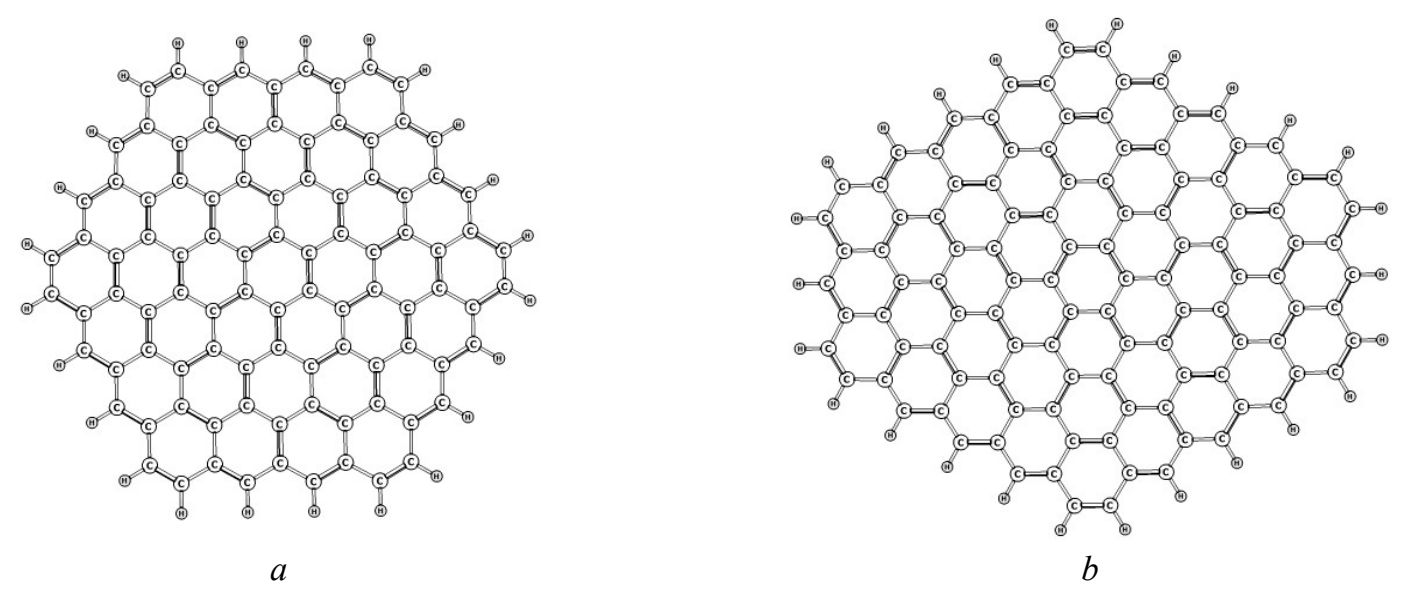

Fig. 2. Models for fragments of graphene-like clusters of gross formula: $a-\mathrm{C}_{96} \mathrm{H}_{24}, b-\mathrm{C}_{110} \mathrm{H}_{26}$ 
The energy of the intermolecular interaction $(\Delta E)$ between the two polyamide fragments was calculated by the formula (1):

$\Delta E=E_{t o t}(\mathrm{AB})-2 *\left(E_{t o t}(\mathrm{~A})\right)$

where $E_{t o t}(\mathrm{~A})$ - the total energy of the monomer or dimer of amide, $E_{t o t}(\mathrm{AB})$ is the total energy of the intermolecular complex of fragments polyamide.

The energy of intermolecular interaction $(\Delta E)$ between one polyamide fragment (monomer or dimer) and GC were calculated by the formula (2):

$\Delta E=E_{t o t}(\mathrm{AB})-\left(\left(E_{t o t}(\mathrm{~A})+E_{t o t}(\mathrm{~B})\right)\right.$

where $E_{\text {tot }}(\mathrm{A})$ is the total energy of the polyamide fragment, $E_{t o t}(\mathrm{~B})$ is the total energy of the GC, $E_{\text {tot }}(\mathrm{AB})$ is the total energy of the intermolecular complex of a fragment of polyamide with a graphene-like cluster.

The energy of intermolecular interaction $(\Delta E)$ between a graphene-like cluster and a complex consisting of two monomers or dimers was calculated by the formula (3):

$\Delta E=\left(E_{t o t}(\mathrm{ABC})-\left(E_{t o t}(\mathrm{AB})+E_{t o t}(\mathrm{C})\right)\right.$

where $E_{\text {tot }}(\mathrm{AB})$ is the total energy of the intermolecular complex consisting of polyamide fragments, $E_{t o t}(\mathrm{C})$ is that of the graphene-like cluster, $E_{t o t}(\mathrm{ABC})$ is the total energy of the intermolecular complex of polyamide with a graphene-like cluster.

The energy of the intermolecular interaction $(\Delta E)$ between the two polyamide fragments, taking into account the graphene-like plane, was calculated by the formula (4):
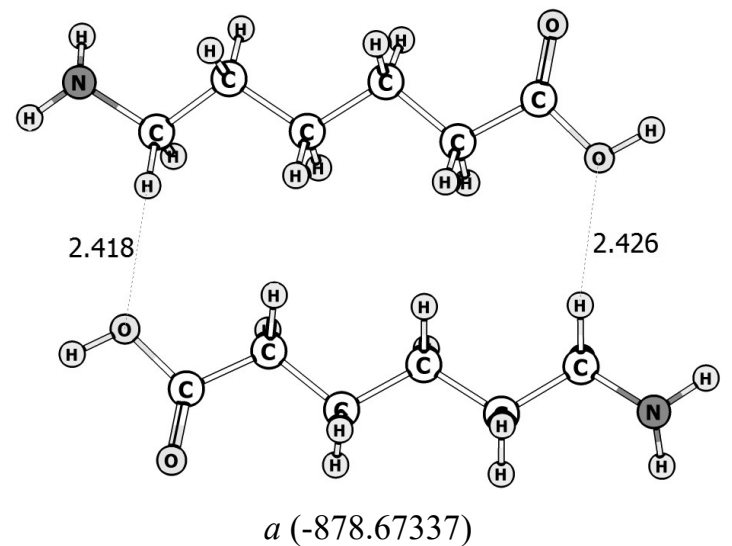

$\Delta E=\left(E_{t o t}(\mathrm{ABC})-\left(E_{t o t}(\mathrm{~A})+E_{t o t}(\mathrm{BC})\right)\right.$

where $E_{t o t}(\mathrm{~A})$ - is the total energy of a polyamide fragment, $E_{t o t}(\mathrm{BC})$ is the total energy of an intermolecular complex containing one fragment of polyamide and a graphene-like cluster, $E_{\text {tot }}(\mathrm{ABC})$ is the total energy of an intermolecular complex consisting of two identical fragments of polyamide and a graphene-like cluster.

\section{RESULTS AND DISCUSSION}

\section{Intermolecular interaction between} polyamide fragments. Due to formation of an intermolecular complex between two amide monomers, there are two hydrogen bonds because each of these monomers has carboxyl and amino groups. When the intermolecular complex is localized, several intermolecular complexes can be formed (Fig. 3). The results of comparison of the total energies for these intermolecular complexes evaluate a thermodynamically more stable complex $b$ (Fig. 3). This is due to the fact that their mutual orientation makes it possible to form two hydrogen bonds of the length of $2.08 \AA$ between the hydrogen atoms of amino groups and oxygen atoms of carbonyl groups, what in turn reduces the total energy for this complex.

The energy of intermolecular interaction, calculated by formula (1) for the complex $a$, is $-42.4 \mathrm{~kJ} / \mathrm{mol}$, and for the complex $b$ is $-86.0 \mathrm{~kJ} / \mathrm{mol}$, respectively (Fig. 3).

The simulation of intermolecular complexes of larger polyamides, two dimers, as well as in the previous case, may result in several mutual orientations of the dimers (Fig. 4).
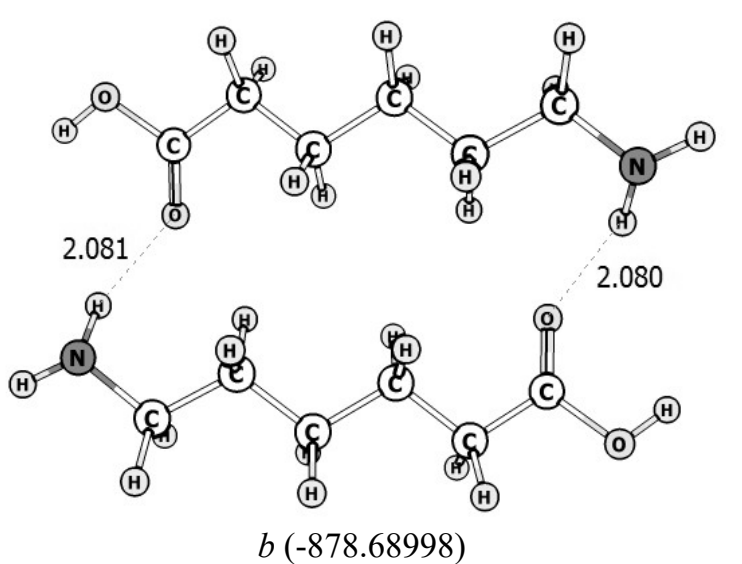

Fig. 3. The most probable intermolecular complexes formed from two monomers of amide $(a)$ and $(b)$ (here and further the distances between atoms in $\AA$, and the total energy of the complexes in Hartree) 

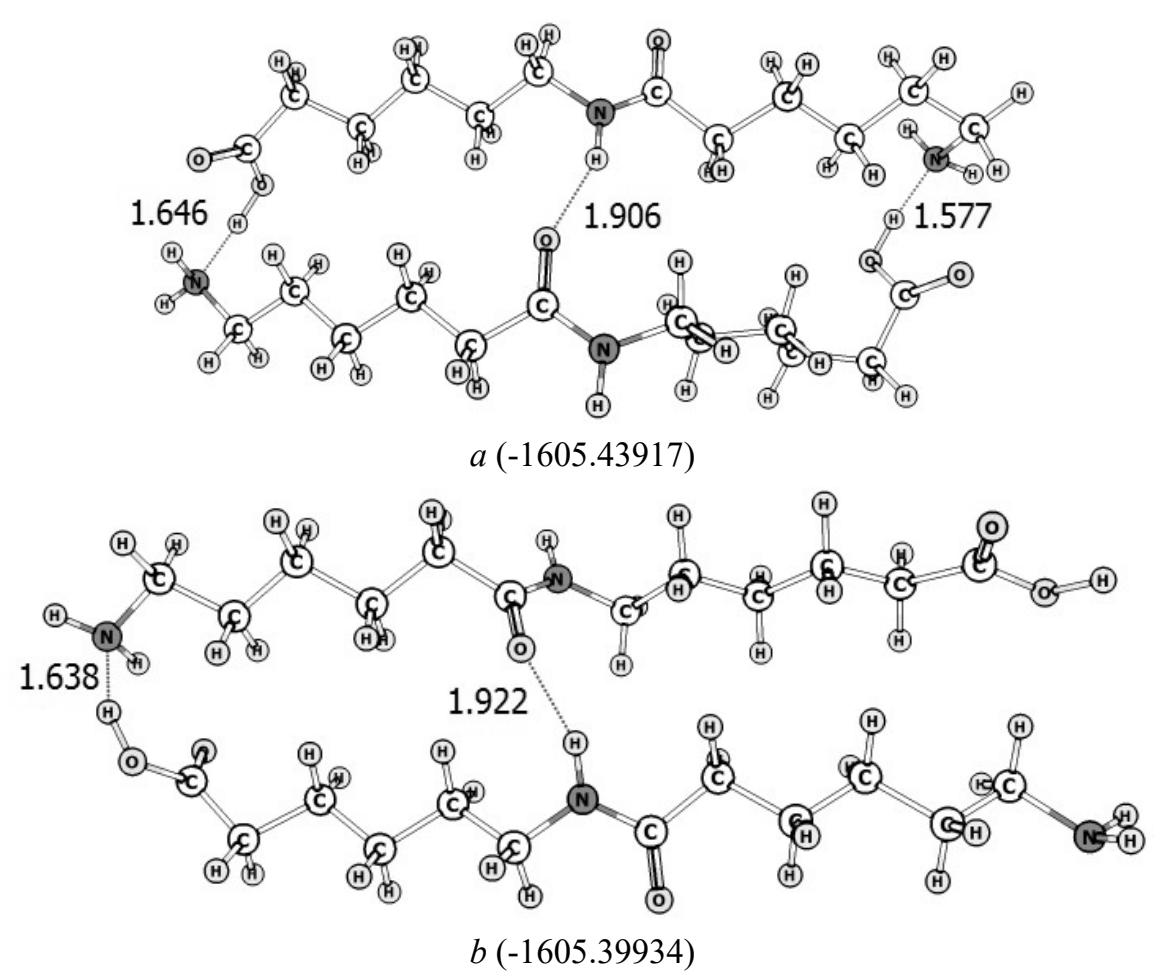

Fig. 4. Possible intermolecular complexes formed of two dimers of amide

Fig. 4 shows that in the structure $a$, dimers form three intermolecular hydrogen bonds, in contrast to the complex $b$, where dimers are bound only by two hydrogen bonds, which may indicate a lower thermodynamic stability of this complex in comparison with that indicated above. In contrast to the complexes discussed above (Fig. 3), in this complex (Fig. 4), there is also a hydrogen bond with the length of $1.9 \AA$, which is formed when two polymeric parts of the polyamide are bonded between the oxygen atom of the amide group of one dimer and the hydrogen atom of the analogous groups of another dimer. This bond is weaker compared to those between the terminal amino and carboxyl groups, which are shorter (about $1.6 \AA$ ).

The results of the analysis of total energies for these intermolecular complexes confirm that the complex $a$ is for $104.5 \mathrm{~kJ} / \mathrm{mol}$ more stable compared to the complex $b$ (Fig. 4). The $\Delta E$ values for these structures are $-302.2 \mathrm{~kJ} / \mathrm{mol}$ (for the complex shown in Fig. $4 a$ ) and $-197.7 \mathrm{~kJ} / \mathrm{mol}$, (Fig. 4 b) respectively. Besides, when comparing the values of the total energy of these two complexes, that of complex $a$ appears to be lower than this value for the complex $b$, so confirming that the first complex is thermodynamically more stable, therefore, it was used in further calculations.

Intermolecular interaction between polyamide fragments and graphene-like planes. Firstly, the interaction of single monomer with fragments of a graphene-like plane of different size with composition of $\mathrm{C}_{96} \mathrm{H}_{24}$ and $\mathrm{C}_{110} \mathrm{H}_{26}$ was considered. As can be seen from Fig. 5, in the formation of these intermolecular complexes, regardless of the size of the $\mathrm{GC}$, the distance between the carbon atoms of the monomer and the carbon atom of the graphene-like plane is almost the same as that between the nitrogen atom of the monomer and that of the graphenelike plane, and is approximately $3 \AA$. This is much greater than those in the above cases for intermolecular complexes consisting of polyamide monomers and dimers (Figs. 3 and 4), what is clear, since there is no specific group in the pure carbon graphene cluster that can form hydrogen bonds. An analysis of the results of calculations of the $\Delta E$ value, calculated according to formula (2), shows that irrespective of the size of the graphene-like cluster, the magnitudes of the intermolecular interaction energy are almost identical $(-117.4 \mathrm{~kJ} / \mathrm{mol}$ for the complex $a$ and $-121.2 \mathrm{~kJ} / \mathrm{mol}$ for the 
complex $b$, respectively, Fig. 5). These values are significantly greater in comparison with the analogous values for an intermolecular complex consisting of two monomers $(-86.0 \mathrm{~kJ} / \mathrm{mol})$, although there is no hydrogen bond formed between the monomer and the graphene-like plane, what indicates the main role of the dispersion term in the interaction energy.

When considering the interaction of a complex containing two monomers connected by two hydrogen bonds (Fig. $3 \mathrm{~b}$ ) with fragments of a graphene-like plane of various sizes, it was found that the hydrogen bonds between monomers were found to be slightly shortened from $2.08 \AA$ to $2.065 \AA$ in the case of using the $\mathrm{C}_{96} \mathrm{H}_{24} \mathrm{GC}$ (Fig. $6 a$ ) and up to $2.027 \AA$ in the complex with the cluster $\mathrm{C}_{110} \mathrm{H}_{26}$ (Fig. 6 b). An analysis of the results of calculations of the $\Delta E$ value by the formula (3) found that when using a cluster of composition $\mathrm{C}_{96} \mathrm{H}_{24}$, it is $-219.0 \mathrm{~kJ} / \mathrm{mol}$, with increased cluster this value increases by $9.1 \mathrm{~kJ} / \mathrm{mol}$ to $-228.1 \mathrm{~kJ} / \mathrm{mol}$. These values are much greater than those in the complexes of graphene-like clusters with single monomer. To find out the influence of the GC on the formation of hydrogen bonds between the monomers, an adequate comparison of these interaction energy quantities is necessary. To do so, these values were divided into two, to determine how much the interaction energy was per monomer: $219.0 / 2=109.5 \mathrm{~kJ} / \mathrm{mol},-228.1 / 2=114.03 \mathrm{~kJ} / \mathrm{mol}$. This is slightly less than the $\Delta \mathrm{E}$ for monomers with $\mathrm{GC}$, for $7.9 \mathrm{~kJ} / \mathrm{mol}$, with the smaller GC size and for $7.2 \mathrm{~kJ} / \mathrm{mol}$ in the case of using the larger graphene cluster.

In order to find out how the presence of a graphene-like cluster affects the interaction energy of two monomers, calculations were made by formula (4) for the complexes including, together with two monomers, the GC of different sizes $\left(\mathrm{C}_{96} \mathrm{H}_{24}\right.$ and $\left.\mathrm{C}_{110} \mathrm{H}_{26}\right)$. An analysis of calculations shows that, when two monomers interact with a GC, regardless of the size of the latter, there is an increase in the energy of the intermolecular interaction between these monomers: from $85.6 \mathrm{~kJ} / \mathrm{mol}$ for two monomers, to $187.6 \mathrm{~kJ} / \mathrm{mol}$ for a complex with the $\mathrm{C}_{96} \mathrm{H}_{24} \mathrm{GC}$ and up to $192.8 \mathrm{~kJ} / \mathrm{mol}$ for the $\mathrm{C}_{110} \mathrm{H}_{26}$ complex. This correlates with the decrease in the hydrogen bond lengths between monomers in the presence of graphene-like planes.

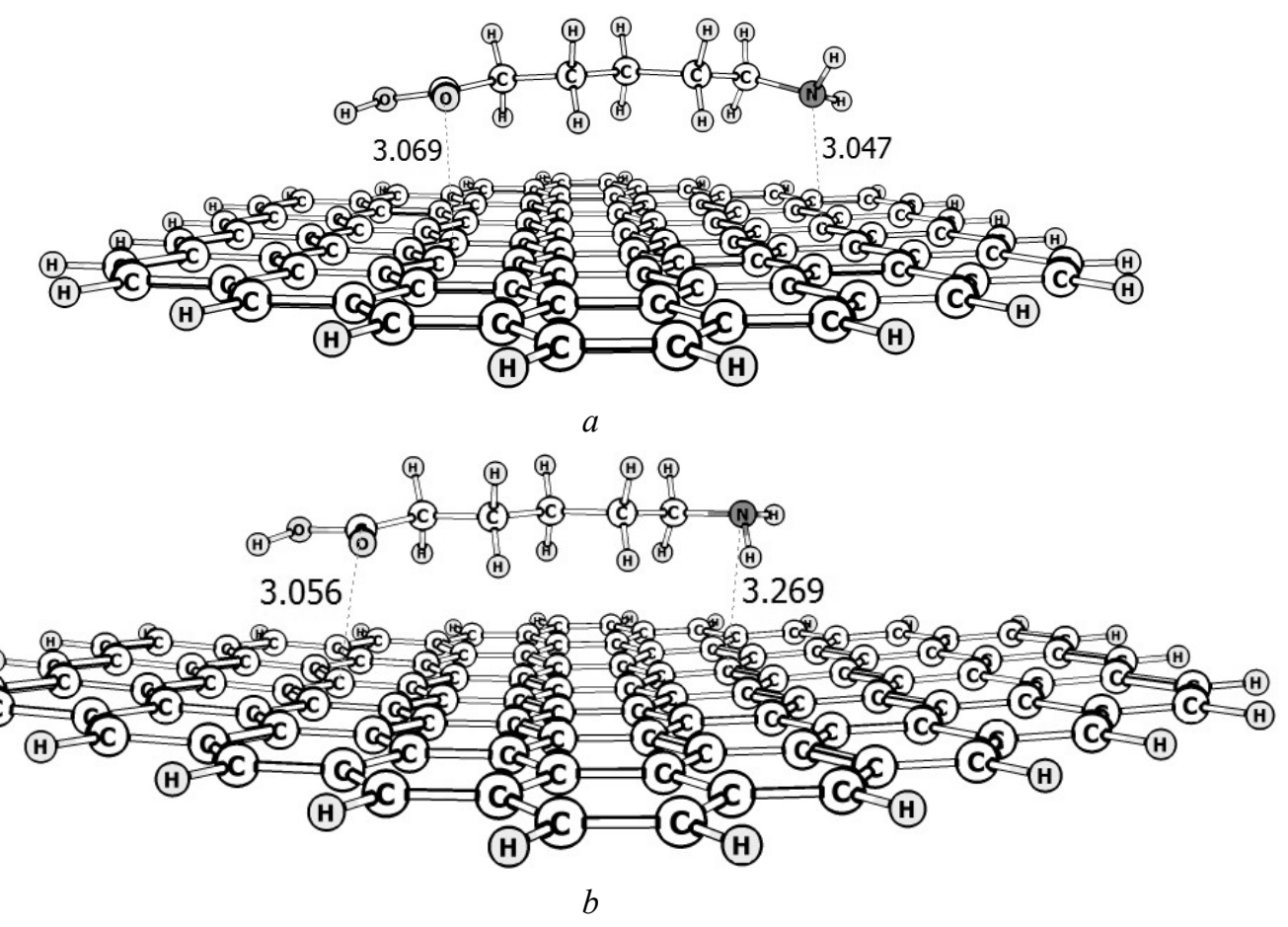

Fig. 5. Possible intermolecular complexes formed from amide monomer and graphene-like clusters of different sizes: $a-\mathrm{C}_{96} \mathrm{H}_{24} . b-\mathrm{C}_{110} \mathrm{H}_{26}$ 

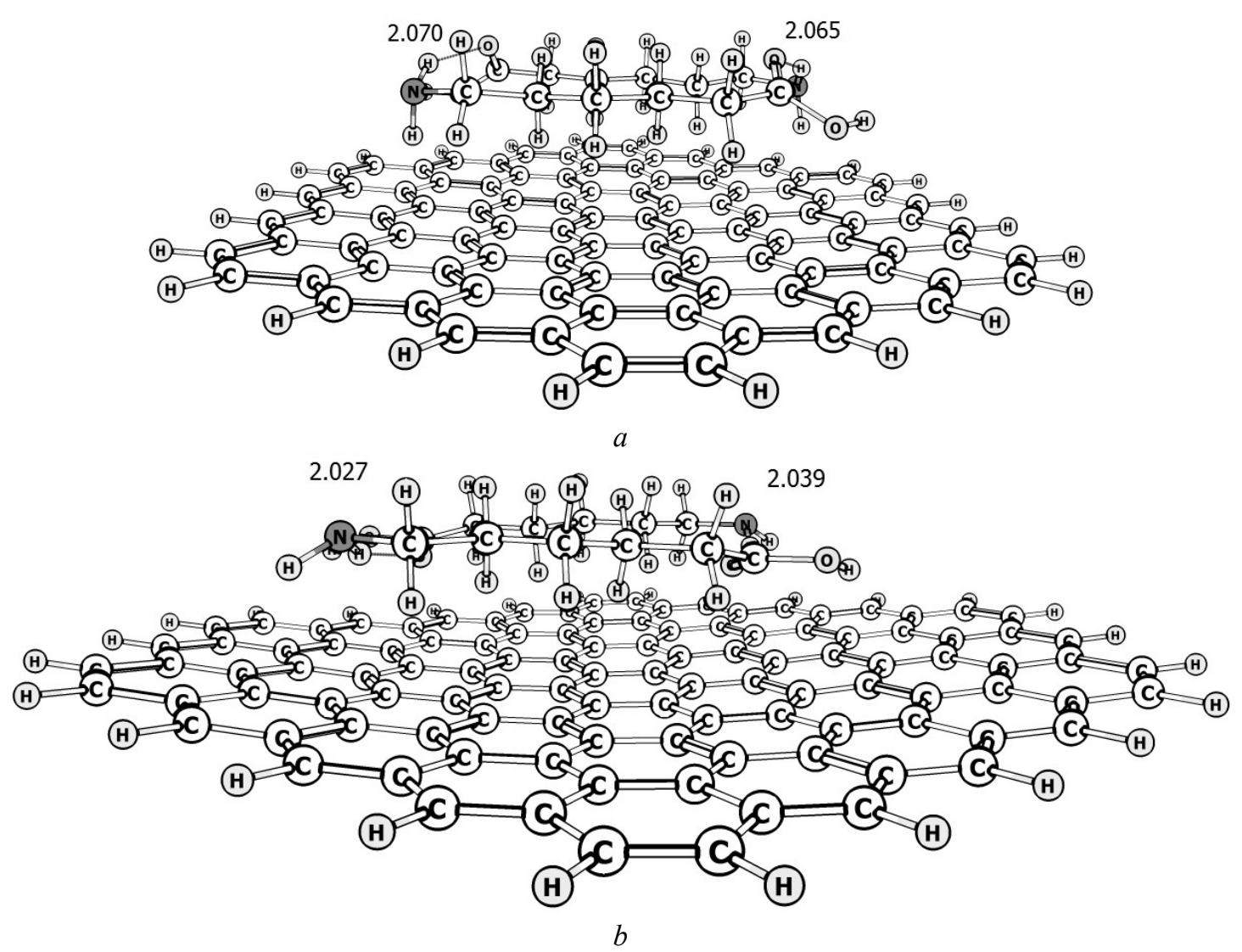

Fig. 6. Equilibrium geometry of intermolecular complexes formed of two monomers of amide and graphene-like clusters of different sizes: $a-\mathrm{C}_{96} \mathrm{H}_{24} . b-\mathrm{C}_{110} \mathrm{H}_{26}$

With an increase in the size of the fragment of the polyamide to the dimer in the complex with the GC, the distance between the molecules, as in the preceding case (Fig. 5), is close to $3 \AA$ (Fig. 7). The energy of the intermolecular interaction calculated by the formula (2), due to the fact that the size of the polyamide fragment is 2 times larger than the previously considered monomers, and is equal, using the $\mathrm{C}_{96} \mathrm{H}_{24} \mathrm{GC}$ to $180.5 \mathrm{~kJ} / \mathrm{mol}$, and with the participation of a larger $\mathrm{GC}$, this $\Delta E$ value increases to $188.0 \mathrm{~kJ} / \mathrm{mol}$. This slight increase in the absolute value of the energy of intermolecular interaction is due to the fact that the size of a smaller graphene-like cluster is not optimal (Fig. $7 a$ ).

In intermolecular complexes built from two dimers and graphene-like clusters (Fig. 8), the hydrogen bond lengths decrease in comparison with those in complexes formed from two dimers (Fig. 4). The reduction of the lengths of hydrogen bonds is similar to the case of the complex of two monomers with a GC, compared to intermolecular complexes with monomers. This indicates that the presence of a carbon matrix (regardless of the GC size) in complexes with polyamide (regardless of the sizes of its fragments) strengthens the hydrogen bonds in the latter (Fig. 6).

An analysis of the energy values calculated in accordance with formula (3), the interaction of a graphene-like fragment with a complex consisting of two dimers of amide is, in the case of using the $\mathrm{C}_{96} \mathrm{H}_{24} \mathrm{GC},-461.7 \mathrm{~kJ} / \mathrm{mol}$, and $-459.7 \mathrm{~kJ} / \mathrm{mol}$, when using the $\mathrm{C}_{110} \mathrm{H}_{26}$ cluster. Calculations by the formula (4) showed that the $\mathrm{GC}$ influences the interaction energy between two polyamide fragments, which is $-346.2 \mathrm{~kJ} / \mathrm{mol}$ for a smaller GC, and $-145.6 \mathrm{~kJ} / \mathrm{mol}$ for a larger fragment of the graphene-like plane. This is greater than the absolute value compared to a similar value between the two dimers $(-302.2 \mathrm{~kJ} / \mathrm{mol})$, which also confirms the strengthening of the waterbound matrix of polyamide fragments in the presence of GC.

Comparison of the energy values of the intermolecular interaction of two monomers $(86.0 \mathrm{~kJ} / \mathrm{mol}$, two hydrogen bonds) and two 
dimers $(-302.0 \mathrm{~kJ} / \mathrm{mol}$, three hydrogen bonds) indicates that the interaction energy of the two components consists of the energy of hydrogen bonds and the energy contribution of the dispersion forces (see Table).
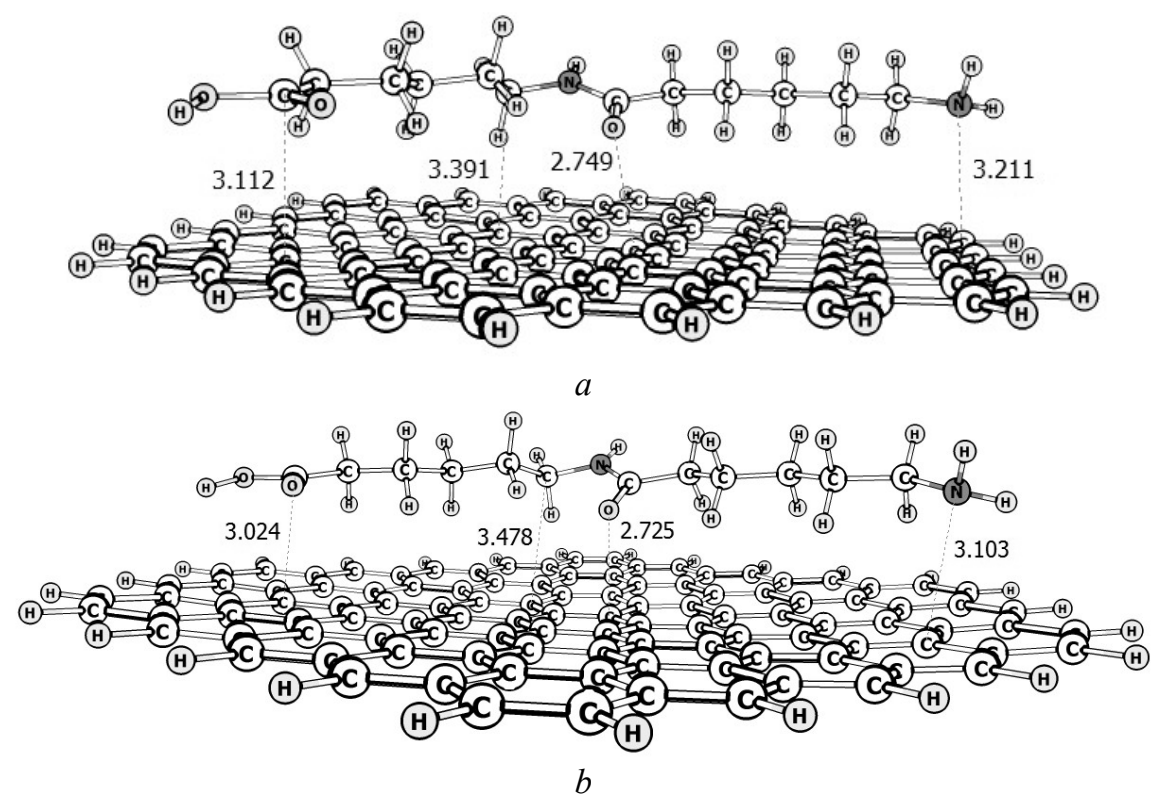

Fig. 7. Possible intermolecular complexes formed of dimer amide and graphene-like clusters of different sizes: $a$ $\mathrm{C}_{96} \mathrm{H}_{24} . b-\mathrm{C}_{110} \mathrm{H}_{26}$
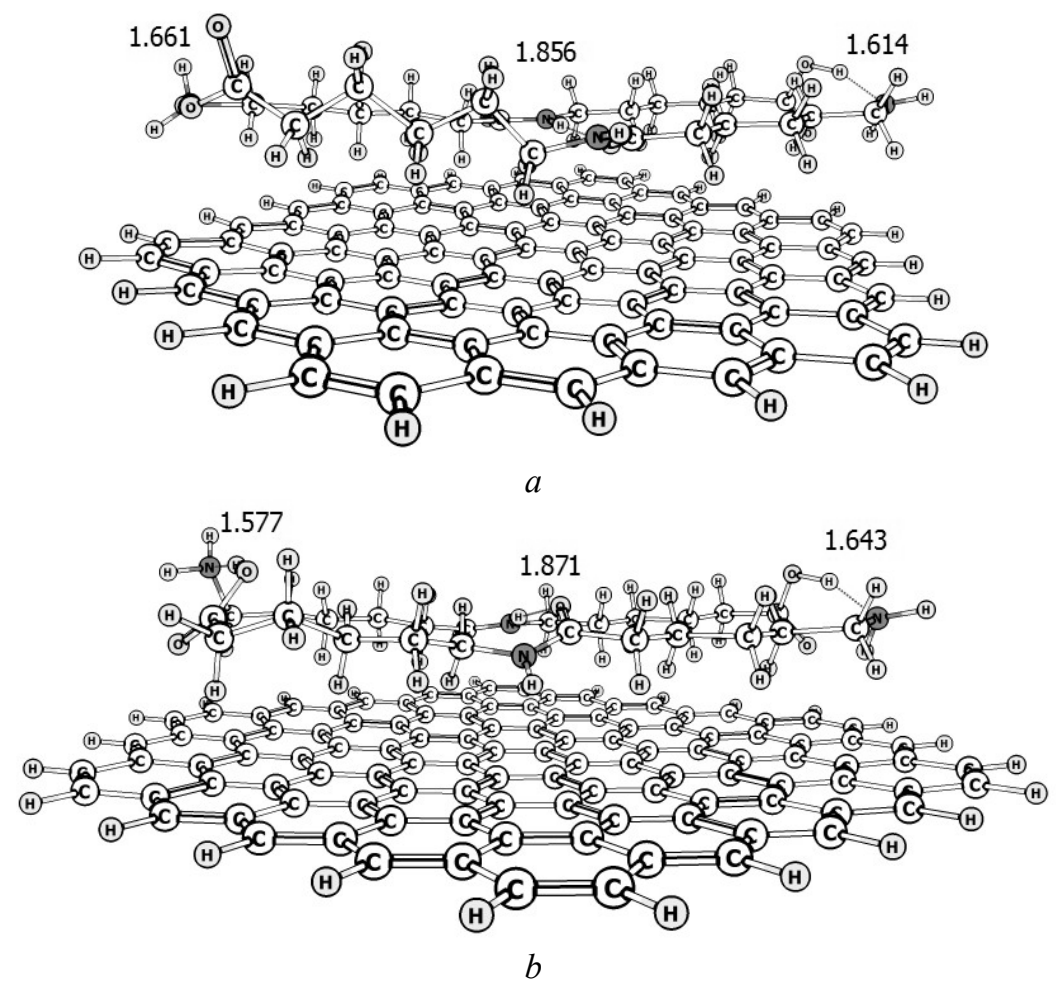

Fig. 8. The most probable intermolecular complexes formed of two dimers of amide and graphene-shaped planes of different sizes: $\mathrm{C}_{96} \mathrm{H}_{24}(a)$ and $\mathrm{C}_{110} \mathrm{H}_{26}(b)$ 
Table. Hydrogen bonds lengths of between polyamide fragments and the intermolecular interaction energy for the corresponding complexes

\begin{tabular}{ccc}
\hline Complex & $\boldsymbol{l}(\mathbf{N}-\mathbf{H} \cdots \mathbf{O}=\mathbf{C}), \boldsymbol{\AA}$ & $\boldsymbol{\Delta E}, \mathbf{k J} / \mathbf{m o l}$ \\
\hline Monomer $\cdots$ monomer & 2.08 & -86.0 \\
Dimer $\cdots$ dimer & 1.91 & -302.2 \\
Monomer $\cdots \mathrm{C}_{96} \mathrm{H}_{24}$ & - & -117.4 \\
Monomer $\cdots \mathrm{C}_{110} \mathrm{H}_{26}$ & - & -121.2 \\
2 Monomer $\cdots \mathrm{C}_{96} \mathrm{H}_{24}$ & 2.06 & -219.0 \\
2 Monomer $\cdots \mathrm{C}_{110} \mathrm{H}_{26}$ & 2.03 & -228.1 \\
Monomer $\cdots$ monomer $-\mathrm{C}_{96} \mathrm{H}_{24}$ & 2.06 & -187.6 \\
Monomer $\cdots$ monomer $-\mathrm{C}_{110} \mathrm{H}_{26}$ & 2.03 & -192.0 \\
Dimer $\cdots \mathrm{C}_{96} \mathrm{H}_{24}$ & - & -180.5 \\
Dimer $\cdots \mathrm{C}_{110} \mathrm{H}_{26}$ & - & -188.4 \\
2 Dimer $\cdots \mathrm{C}_{96} \mathrm{H}_{24}$ & 1.86 & -346.2 \\
2 Dimer $\cdots \mathrm{C}_{110} \mathrm{H}_{26}$ & 1.87 & -345.6 \\
Dimer $\cdots$ dimer $-\mathrm{C}_{96} \mathrm{H}_{24}$ & 1.86 & -461.8 \\
Dimer $\cdots$ dimer $-\mathrm{C}_{110} \mathrm{H}_{26}$ & 1.87 & -459.7 \\
\hline
\end{tabular}

As can be seen from the Table, the energy of the intermolecular interaction of two dimers with a graphene matrix $\left(\mathrm{C}_{110} \mathrm{H}_{26}\right)$ is approximately for $40 \mathrm{~kJ} / \mathrm{mol}(-346.2 \mathrm{~kJ} / \mathrm{mol})$ greater compared to the similar value for two dimmers $(-302.2 \mathrm{~kJ} / \mathrm{mol})$. The lesser $\Delta E$ value $(-325.0 \mathrm{~kJ} / \mathrm{mol})$ for the $\mathrm{C}_{96} \mathrm{H}_{24}$ nanocomposite is due to the insufficient size of the selected model for the graphene matrix.
An intermolecular complex consisting of two monomers and a $\mathrm{GC} \quad \mathrm{C}_{96} \mathrm{H}_{24}$ species (Monomer...Monomer... $\mathrm{C}_{96} \mathrm{H}_{24}$ ) with the energy effect of $-305 \mathrm{~kJ} / \mathrm{mol}$ can be formed in two ways (Fig. 9). The first of these involves the formation of an intermolecular complex between two monomers, which further interacts with GC $\mathrm{C}_{96} \mathrm{H}_{24}$ :

Monomer + Monomer $\rightarrow$ Monomer... Monomer

Monomer. . Monomer $+\mathrm{C}_{96} \mathrm{H}_{24} \rightarrow$ Monomer... Monomer. . $\mathrm{C}_{96} \mathrm{H}_{24}$

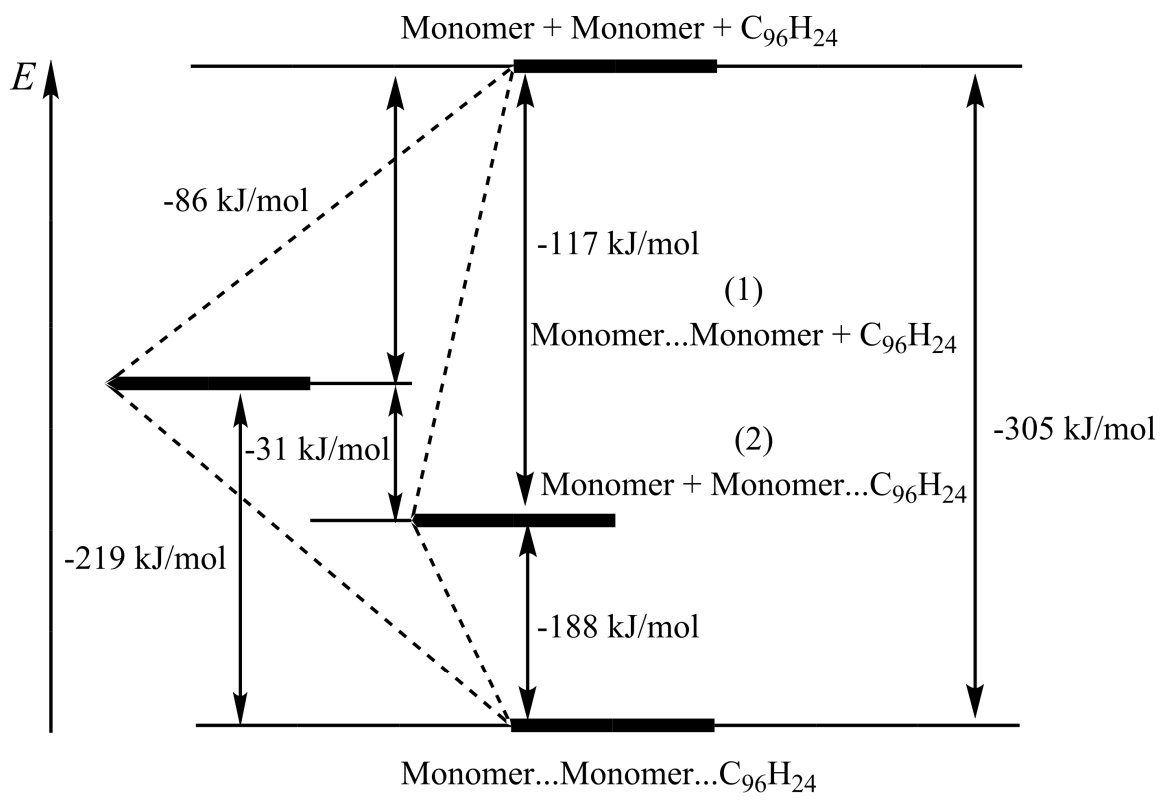

Fig. 9. Energy diagram of the interaction of two monomers with a $\mathrm{C}_{96} \mathrm{H}_{24}$ graphene cluster 
As can be seen from Fig. 9, when adding the energy effect of the formation of the Monomer... Monomer complex (reaction $a$ ) with a similar magnitude of the interaction of the Monomer...Monomer complex and GC (reaction $b$ ), the same value $-305 \mathrm{~kJ} / \mathrm{mol}$ is obtained $(-86+(-219))$, as in full energy difference: $E_{\text {tot }}$ (Monomer... Monomer.... $\mathrm{C}_{96} \mathrm{H}_{24}$ ) and two $E_{\text {tot }}$ (Monomer) and $E_{\text {tot }}\left(\mathrm{C}_{96} \mathrm{H}_{24}\right)$.

According to the second path, the first interaction of one monomer with $\mathrm{GC} \mathrm{C}_{96} \mathrm{H}_{24}$ (reaction $c$ ), and then the addition of another monomer (reaction $d$ ):

Monomer $+\mathrm{C}_{96} \mathrm{H}_{24} \rightarrow$ Monomer... $\mathrm{C}_{96} \mathrm{H}_{24}$

Monomer... $+\mathrm{C}_{96} \mathrm{H}_{24} \ldots$ Monomer $\rightarrow$ Monomer... Monomer... $\mathrm{C}_{96} \mathrm{H}_{24}$

The sum of the energy effects of these two reactions $(-117+(-188)$ is also $-305 \mathrm{~kJ} / \mathrm{mol}$. This means that regardless of the path of formation of the intermolecular Monomer ... Monomer ... $\mathrm{C}_{96} \mathrm{H}_{24}$ complex, the magnitudes of the total energy effect are the same, which confirms the correctness of our calculations. It should be noted that this pattern is similar to the Hess law in thermochemistry, if we assume that the energy effect of the reaction at $0 \mathrm{~K}$ corresponds to the enthalpy of the reaction.

Similar dependences can be obtained for the systems with dimers and $\mathrm{C}_{110} \mathrm{H}_{26}$. It should be noted that Fig. 9 shows that the sum of the total energies (1) of the complex of two monomers and the graphene plane is for $31 \mathrm{~kJ} / \mathrm{mol}$ higher than that (2) of the monomer and intermolecular complex (monomer... $\mathrm{C}_{96} \mathrm{H}_{24}$ ). This indicates that the interaction energy of GC with the monomer is greater than that of two monomers.

An analysis of the hydrogen bond lengths between the oxygen atom of the carbonyl group and the hydrogen atom of the amino group indicates that, regardless of the length of the linkage of the polymeric chain of polyamide (monomer and dimer) and the size of the graphene-like matrix $\left(\mathrm{C}_{96} \mathrm{H}_{24}\right.$ and $\left.\mathrm{C}_{110} \mathrm{H}_{26}\right)$ in the nanocomposite (Fig. 8), the hydrogen bond is shorter in comparison with similar findings in the complexes without a carbon matrix. This indicates a greater strength of the bond, that is, the presence of a carbon matrix increases the strength of the formed nanocomposite, what explains the increase in the melting point compared with that for the original polymer.

\section{CONCLUSIONS}

Thus, in the nanocomposite polyamide carbon matrix for all the models studied, the intermolecular interaction energy increases significantly compared to a similar value between two fragments of pure polyamide, indicating an increase in the thermal stability of the matter.

The presence of a carbon matrix (regardless of the size of the graphene cluster) in complexes with polyamide (regardless of the size of its fragments) strengthens the hydrogen bonds in the latter.

In the nanocomposite polyamide - a fragment of carbon nanotube, the energy of all investigated covalent bonds significantly increases compared to those in pure polyamide, what indicates an increase in the thermal stability of this nanocomposite. The indicated results of calculations are confirmed by experimental data [6]. 


\title{
Теоретичне дослідження впливу вуглецевого графеноподібного нанокластера на стабільність і міцність поліаміду у нанокомпозиті
}

\author{
С.М. Дем'яненко, М.І. Терець, Ю.І. Семенцов, С.М. Махно, В.С. Куць, А.Г. Гребенюк, М.Т. Картель \\ Інститут хімії поверхні ім. О.О. Чуйка Національної академії наук Украӥни \\ вул. Генерала Наумова, 17, Київ, 03164, Україна, Demianenko_en@ukr.net
}

Методом теорії функиіоналу густини з обмінно-кореляційним функціоналом ВЗLҮР, базисним набором 6-31G(d,p) i дисперсійною поправкою Грімме розраховані величини енергії міжмолекулярної взаємодії між сусідніми фрагментами поліаміду та встановлено вплив графеноподібних нанокластерів на аналогічні величини для міжмолекулярних комплексів фрагментів поліаміду з графеноподібними нанокластерами. Також досліджено вплив вуглецевих матеріалів на величини енергї ковалентних зв'язків в полімерній матриці поліаміду.

Порівняння величин енергї̈ міжмолекулярної взаємодії двох мономерів (-86.0 кДж/моль, два водневих зв'язки) і двох димерів (-302.0 кДж/моль, три водневих зв'язки) вказує, щзо величина енергії взаємодії двох ланок складається з енергії водневих зв'язків та внеску енергії дисперсійних сил взаємодії.

Енергія міжмолекулярної взаємодії двох димерів з графеноподібною матрицею $\left(C_{110} H_{26}\right)$, приблизно на 40 кДж/моль більша (-346.2 кДж/моль) в порівнянні з аналогічною величиною для двох димерів. Менше значення енергії взаємодії (-325.0 кДж/моль) для нанокомпозиту з матрицею $C_{96} H_{24}$ обумовлене недостатнім розміром вибраної моделі графеноподібної матриці.

Аналіз довжин водневого з6'язку між атомом Оксигену карбонільної групи $i$ атомом Гідрогену аміногрупи свідчить, щчо незалежно від довжини ланки полімерного ланщюга поліаміду (мономер $і$ димер) та розміру графеноподібної матриці ( $\mathrm{C}_{96} \mathrm{H}_{24}$ i $\left.\mathrm{C}_{110} \mathrm{H}_{26}\right)$ в нанокомпозиті, водневий зв'язок коротший в порівнянні з аналогічною величиною в комплексах без вуглецевої матриці. Це свідчить про більшу міцність даного зв'язку, тобто наявність вуглецевої матриці збільиує міцність утвореного нанокомпозиту, щзо $і$ пояснює підвищення температури плавлення в порівнянні з вихідним полімером. В утвореному нанокомпозиті поліамід - вуглечева матричя для всіх досліджених моделей енергія міжмолекулярної взаємодї в нанокомпозиті значно збільшується у порівнянні з аналогічною величиною між двома фрагментами чистого поліаміду, що свідчить про підвищення термічної стійкості даного нанокомпозиту та підтверджується експериментальними даними.

Ключові слова: поліамід, нанокомпозит, графеноподібна площцна, метод теорії функціоналу густини, кластерне наближення

\section{Теоретическое исследование влияния углеродного графеноподобного нанокластера на стабильность и прочность полиамида в нанокомпозите}

\author{
Е.Н. Демяненко, М.И. Терец, Ю.И. Семенцов, С.Н. Махно, В.С. Куц, А.Г. Гребенюк, Н.Т. Картель \\ Институт химии поверхности им. А.А. Чуйко Наџиональной академии наук Украины \\ ул. Генерала Наумова, 17, Киев, 03164, Украина, Demianenko_en@ukr.net
}

Методом теории функционала плотности с обменно-корреляциионным функционалом В3LYP, базисным набором 6-31G $(d, p)$ и дисперсионной поправкой Гримме рассчитаны величины энергии межмолекулярного взаимодействия между соседними фрагментами полиамида и установлено влияние графеноподобных нанокластеров на аналогичные величины межмолекулярных комплексов фрагментов полиамида с графеноподобнымы нанокластерами. Также исследовано влияние углеродных материалов на прочность ковалентных связей в полимерной матрище полиамида.

Сравнение величин энергии межмолекулярного взаимодействия двух мономеров (-86.0 кДж/моль, две водородные связи) и двух димеров (-302.0кДж/моль, три водородные связи) указывает, что величина энергии взаимодействия двух звеньев состоит из энергии водородных связей и вклада энергии дисперсионных сил взаимодействия.

Энергия межмолекулярного взаимодействия двух димеров с графеноподобной матрищей $\left(C_{110} H_{26}\right)$ примерно на 40 кДж/моль больще (-346.2 кДж/моль) по сравнению с аналогичной величиной для двух 
димеров. Меньшее значение энергии взаимодействия (-325.0кДж/моль) для нанокомпозита с С $_{96} H_{24}$ обусловлено недостаточным размером выбранной модели графеноподобной матриць.

Анализ длин водородных связей между атомом кислорода карбонильной группь и атомом водорода аминогруппы свидетельствует, что независимо от длины звена полимерной цепи полиамида (мономер и димер) и размера графеноподобной матрицы $\left(\mathrm{C}_{96} \mathrm{H}_{24}\right.$ и $\left.\mathrm{C}_{110} \mathrm{H}_{26}\right)$ в нанокомпозитах, водородная связь короче по сравнению с аналогичной величиной в комплексах без углеродной матриць. Это свидетельствует о большей прочности данной связи, то есть, наличие углеродной матриць увеличивает прочность образованного нанокомпозита, что и объясняет повышение температуры плавления по сравнению с исходным полимером. В образованном нанокомпозите полиамид - углеродная матрица для всех исследованных моделей энергия межмолекулярного взаимодействия в нанокомпозитоах значительно увеличивается по сравнению с аналогичной величиной между двумя фрагментами чистого полиамида, что свидетельствует о повышении термической устойчивости данного нанокомпозита и подтверждается экспериментальными данными.

Ключевье слова: полиамид, нанокомпозит, графеноподобная плоскость, метод теории функиионала плотности, кластерное приближение

\section{REFERENCES}

1. Shaoyun Fu, Zheng Sun, Pei Huang, Yuanqing Li Ning Hu. Some basic aspects of polymer nanocomposites: A critical review. Nano Materials Science. 2019. 1(1): 2.

2. Zeranska-Chudek K., Lapinska A., Wroblewska A., Judek J., Duzynska A., Pawlowski M., Witowski A.M., Zdrojek M. Study of the absorption coefficient of graphene-polymer composites. Sci. Rep. 2018. 8: 9132.

3. Krychkov Y.A., Krychkov M.V., Vymorkov N.V. Portnova Y.M., Bushansky N.V., Bushansky S.N. Preparation of polymeric nanocomposites by using granulated multilayer carbon nanotubes. Composites and nanostructures. 2014. 6(4):223. [in Russian].

4. Chesnokov N.V., Kuznetsov B.N., Mikova N.M. Synthesis and Properties of Carbonaceous and Composite Materials from Natural Graphite. Journal of Siberian Federal University. Chemistry. 2013. 6(1): 11. [in Russian].

5. Wang M., Yan C., Lin M. Graphene Nanocomposites. Composites and Their Properties. 2012: 17.

6. Lau K.T. Interfacial bonding characteristics of nanotube/polymer composites. Chem. Phys. Lett. 2003. 370(3-4): 399.

7. Mishchenko S.V., Tkachev A.G. Carbon Nanomaterials. Production, Properties, Application. (Moscow: Mechanical engineering, 2008). [in Russian].

8. Coleman J.N., Curran S., Dalton A.B., Davey A.P., McCarthy B., Blau W., Barklie R.C. Percolation-dominated conductivity in a conjugated-polymer-carbon-nanotube composite. Phys. Rev. B. 1998. 58: 7492.

9. Lisova O.M., Makhno S.M., Gunya G.M., Sementsov Yu.I., Kartel M.T. Electronic power systems polyamide graphene nanoplates. Nanosistemi, Nanomateriali, Nanotehnologii. 2017. 15(2): 289. [In Ukrainian].

10. Kartel M., Sementsov Yu., Makhno S., Trachevskiy V., Wang Bo. Polymer composites filled with multiwall carbon nanotubes. Universal J. Mater Sci. 2016. 4(2): 23.

11. Zhang Q., Zhao X., Sui G., Yang X. Surface sizing treated MWCNTs and its effect on the wettability, interfacial interaction and flexural properties of MWCNT/Epoxy nanocomposites. Nanomaterials (Basel). 2018. 8(9): 680 .

12. Khostavan S., Fazli M., Ahangari M.G. Rostamiyan Y. The effect of interaction between nanofillers and epoxy on mechanical and thermal properties of nanocomposites: theoretical prediction and experimental analysis. $A d v$. Polym. Tech. 2019. 4: 1.

13. Mehdizadeh K., Giahi M. A DFT study on N-6-amino-hexylamide functionalized single-walled carbon nanotubes in interaction with silver ion in a gaseous environment. J. Nanostructure Chem. 2019. 9(1): 39.

14. Terets M.I., Demianenko E.M., Zhuravsky S.V. Chernyuk O.A., Kuts V.S., Grebenyuk A.G., Sementsov Yu.I., Kokhtych L.M., Kartel M.T. Quantum chemical study on the interaction of carbon nanotube with polyethylene and polypropylene oligomers. Him. Fiz. Tehnol. Poverhni. 2019. 10(1): 75.

15. Sementsov Yu.I., Makhno S.N., Zhuravsky S.V., Kartel M.T. Properties of polyethylene-carbon nanotubes composites Him. Fiz. Tehnol. Poverhni. 2017. 8(2): 107. [in Ukrainain].

16. Sementsov Yu.I., Prikhodko G.P, Kartel N.T., Makhno S.M., Grabovsky Yu.E., Aleksyeyev O.M., PinchukRugal T.M. Polypropylene-carbon nanotubes composites: structural features, physical and chemical properties. Surface. 2012. 4(19): 203. [in Ukrainain]. 
17. Sun S.F. Physical Chemistry of Macromolecules: Basic Principles and Issues. (New York: Wiley, 2004).

18. Becke A.D. Density functional thermochemistry. III. The role of exact exchange. J. Chem. Phys. 1993. 98(7): 5648.

19. Lee C., Yang W., Parr R.G. Development of the Colle-Salvetti correlation-energy formula into a functional of the electron density. Phys. Rev. B. 1988. 37(2): 785.

20. Grimme S., Ehrlich S., Goerigk L. Effect of the damping function in dispersion corrected density functional theory. J. Comput. Chem. 2011. 32: 1456.

21. Grimme S. Density functional theory with London dispersion corrections. WIREs Comput. Mol. Sci. 2011. 1: 211.

22. Schmidt M.W., Baldridge K.K., Boatz J.A., Elbert S.T., Gordon M.S., Jensen J.H., Koseki S., Matsunaga N., Nguyen K.A., Su S.J., Windus T.L., Dupuis M., Montgomery J.A. General atomic and molecular electronic structure system. J. Comput. Chem. 1993. 14(11): 1347.

Received 09.07.2019, accepted 20.11.2019 